\title{
TU/e EmonONEN

\section{Effect of surface treatment of apricot shell on the performance of lightweight bio-concrete}

\section{Citation for published version (APA):}

Wu, F., Yu, Q., Liu, C., Brouwers, J., \& Wang, L. (2019). Effect of surface treatment of apricot shell on the performance of lightweight bio-concrete. Construction and Building Materials, 229, [116859].

https://doi.org/10.1016/j.conbuildmat.2019.116859

\section{Document license: \\ TAVERNE}

DOI:

10.1016/j.conbuildmat.2019.116859

Document status and date:

Published: 30/12/2019

\section{Document Version:}

Publisher's PDF, also known as Version of Record (includes final page, issue and volume numbers)

\section{Please check the document version of this publication:}

- A submitted manuscript is the version of the article upon submission and before peer-review. There can be important differences between the submitted version and the official published version of record. People interested in the research are advised to contact the author for the final version of the publication, or visit the $\mathrm{DOI}$ to the publisher's website.

- The final author version and the galley proof are versions of the publication after peer review.

- The final published version features the final layout of the paper including the volume, issue and page numbers.

Link to publication

\section{General rights}

Copyright and moral rights for the publications made accessible in the public portal are retained by the authors and/or other copyright owners and it is a condition of accessing publications that users recognise and abide by the legal requirements associated with these rights.

- Users may download and print one copy of any publication from the public portal for the purpose of private study or research.

- You may not further distribute the material or use it for any profit-making activity or commercial gain

- You may freely distribute the URL identifying the publication in the public portal.

If the publication is distributed under the terms of Article 25fa of the Dutch Copyright Act, indicated by the "Taverne" license above, please follow below link for the End User Agreement:

www.tue.nl/taverne

Take down policy

If you believe that this document breaches copyright please contact us at:

openaccess@tue.nl

providing details and we will investigate your claim. 


\title{
Effect of surface treatment of apricot shell on the performance of lightweight bio-concrete
}

\author{
Fan $\mathrm{Wu}^{\mathrm{a}, \mathrm{b}}$, Qingliang $\mathrm{Yu}^{\mathrm{a}, *}$, Changwu Liu ${ }^{\mathrm{b}, \mathrm{c}, \mathrm{d}, *, 1}$, H.J.H. Brouwers ${ }^{\mathrm{a}}$, Linfeng Wang ${ }^{\mathrm{e}}$ \\ ${ }^{a}$ Department of the Built Environment, Eindhoven University of Technology, P.O. Box 513, 5600 MB Eindhoven, The Netherlands \\ ${ }^{\mathrm{b}}$ Institute of Disaster Management and Reconstruction, Sichuan University-The Hong Kong Polytechnic University, No.1 Huanghe Road, Chengdu 610065, China \\ ${ }^{c}$ College of Water Resource and Hydropower, Sichuan University, No.24 South Section 1, Yihuan Road, Chengdu 610065, China \\ ${ }^{\mathrm{d}}$ State Key Laboratory of Hydraulics and Mountain River Engineering, Sichuan University, No.24 South Section 1, Yihuan Road, Chengdu 610065, China \\ ${ }^{\mathrm{e}}$ Key Laboratory of Geological Hazards Mitigation for Mountainous Highway and Waterway, Chongqing Jiaotong University, No. 66 Xuefu Avenue, Nanan District, Chongqing \\ 400074, China
}

\section{H I G H L I G H T S}

- Five different surface treatments were applied to apricot shell.

- Surface treated apricot shells are used as aggregates for lightweight bio-concrete.

- Evaluation of treatments on physical properties of lightweight bio-concrete.

- Evaluation of treatments on mechanical properties of lightweight bio-concrete.

- Evaluation of treatment on durability of lightweight bio-concrete.

\section{A R T I C L E I N F O}

Article history:

Received 8 February 2019

Received in revised form 4 August 2019

Accepted 1 September 2019

\section{Keywords:}

Apricot shell

Lightweight aggregate

Surface treatment

Mechanical properties

Magnesium sulfate attack

\begin{abstract}
A B S T R A C T
The effects of different surface treatment of apricot shell (AS) on the performance of concrete were investigated. Five surface treatments were used to treat the AS, including soaking AS with cement solution (CS), waterproof agent (WP), sodium silicate (SS), white latex (WL), and coating AS with wood oil (WO). The results showed that the WP and CS treatments improved the physical properties, mechanical strength and resistance to magnesium sulfate of apricot shell bio-concrete (ASC). The WP treatment increased the density and decreased the porosity and water absorption of concrete. The compressive strength, splitting tensile strength, flexural strength, modulus of elasticity of the WP treated bioconcrete improved $9.3 \%, 16.3 \%, 15.1 \%$ and $19.2 \%$, respectively, compared to the untreated mixture. The SS and WL treatments had a negligible influence on the performance of ASC. However, the WO treatment significantly increased the porosity, which resulted in a reduction in mechanical properties and resistance to magnesium sulfate. The WP and CS treatments enhanced the resistance to magnesium sulfate of ASC. It is concluded that the AS treated with waterproof agent is an effective method to enhance both the mechanical properties and durability of the developed lightweight bio-concrete.
\end{abstract}

(c) 2019 Elsevier Ltd. All rights reserved.

\section{Introduction}

Apricot is one of the most cultivated fruits around the world, especially in Asia and Europe [1]. In 2014, the output of apricot in China was 2.68 million tons [2]. By 2015, the cultivated area of apricot reached 0.55 million hectares and the output was 3.13

\footnotetext{
* Corresponding authors at: Institute of Disaster Management and Reconstruction, Sichuan University-The Hong Kong Polytechnic University, No.1 Huanghe Road, Chengdu 610065, China (C. Liu).

E-mail addresses: q.yu@bwk.tue.nl (Q. Yu), liuchangwu@scu.edu.cn (C. Liu).

1 ORCID: https://orcid.org/0000-0002-0450-0040.
}

million tons [3]. Apricot shells (AS) are an agricultural waste resulting from the processing of apricot. Currently, the recycled AS is mainly used as a raw material for activated carbon to remove pollutions from wastewater [4,5], a potential fuel for clean energy in small-scale fruit industry [6], or a low-cost soil amendment to improve soil fertility [7]. For reducing the consumption of natural aggregate and achieving sustainable development of concrete, various wastes are applied as ingredients for the production of ecofriendly concrete, such as wood [8], oil palm shell [9], coconut shell [10], etc. Because of the lightweight and high stiffness properties of the AS, it is also used as aggregates to produce structural lightweight concrete [11]. Yildiz et al. [12] reported that the oven-dry 
density of concrete containing $40 \%$ AS was $1840 \mathrm{~kg} / \mathrm{m}^{3}$, which reduced the density by $23.3 \%$, compared to the ordinary concrete of $2400 \mathrm{~kg} / \mathrm{m}^{3}$. The use of AS as alternative aggregates in concrete can contribute to eco-friendliness and low-cost due to its renewability [11].

The performance of concrete also is strongly related to the characteristics and loading-carrying capacity of the used aggregates [13]. The porous nature of the AS and the surface smooth textures result in the weak bond between the AS and the surrounding mor$\operatorname{tar}$ [11]. Moreover, the biological degradation feature of AS also affects the long-term performance of concrete [14]. This is mainly because the organic material is composed of cellulose, lignin and hemicellulose, such as wood, bamboo and oil palm shell, which can easily decomposed [15], resulting in the increase of brittleness and decrease of mechanical strength over time. Besides, the sugar leached from the organic material also affects the cement hydration and microstructure [16] and weakens the bond between the organic aggregate and the mortar [17]. Therefore, the porous nature of the AS and the weak bond in the interfacial transition zone (ITZ) are considered as one of the main factors that influence the performance of concrete containing AS. For the porous AS aggregate, to improve its surface properties and increase its adhesion to the mortar interface, surface treatment of organic aggregates should be considered.

$\mathrm{Su}$ et al. [18] reported that the service life of preservativetreated wood can be extended by 5-20 times. Compared to untreated wood, the durability, weathering resistance as well as dimensional stability was also improved. Considering organic aggregates, heat treatment and soaking with chemical solutions are common method to improve the surface properties of aggregates. Although heat treatment can significantly increase the bonding ability of the organic aggregate and mortar interface by pyrolysis of organic components [17,19], the pyrolysis process produces $\mathrm{CO}$ and $\mathrm{NO}_{x}$ [6], and heat treatment also requires energy. Therefore, treating organic aggregates by various chemical solutions has received more attention.

Generally, these chemical solutions include alkaline solutions [20], polyvinyl alcohol [21], cement paste solution [22], wood oil [23], sodium silicate [24] and waterproof agents [25] etc. Surface coating treatment may improve the mechanical properties and resistance to chemical attack of concrete by forming a film on the surface of aggregates [21], which reduces the moisture transfer through porous organic aggregates [26] and prevents the leaching of sugar. Moreover, coating treatment increased the rigidity of the wood and enhances its resistance against insect and fungal attack [22]. Thong et al. [13] reported that the dispersion effect of polyvinyl alcohol may alter the flocculation state of the mortar near the aggregate surface through preventing the formation of a porous layer in the ITZ, which leads to a denser aggregate-mortar interface, and subsequently decreased water absorption of concrete. Coatanlem et al. [24] reported that sodium silicate treated wood chippings improved its adhesion to mortar. The addition of the waterproof agent in concrete can reduce its water absorption [25] and increase its mechanical properties and resistance to salt frost [27]. Therefore, the surface treated aggregate not only increases the mechanical properties of concrete but also improves the durability.

Previous studies about ASC focused on mixing proportion, fibre reinforcement, and bonding ability between the mortar and the AS
$[11,12,14,17]$. To apply apricot shell bio-concrete (ASC) in constructions and buildings, suitable surface treatment method for apricot shell (AS) should be investigated. In this study, the effects of different surface treatment of AS on mechanical properties and durability of concrete were investigated. Five surface treatments were used to treat the AS, including soaking AS with cement solution (CS), waterproof agent solution (WP), sodium silicate solution (SS), white latex solution (WL), and coating AS with wood oil (WO). The properties of the treated AS, the physical properties, mechanical strength and long-term resistance to magnesium sulfate attack of ASC were investigated.

\section{Materials and methods}

\subsection{Materials}

The cement used was Type I 42.5 grade Portland cement (Southwest Cement Company, Chengdu, China). The composition of cement is shown in Table 1 . The specific density and Blaine specific surface area were $3.14 \mathrm{~g} / \mathrm{cm}^{3}$ and $3532 \mathrm{~cm}^{2} / \mathrm{g}$, respectively.

Because the particle size of the apricot shell (AS) is usually about $15 \mathrm{~mm}$, it is difficult to obtain a large-sized AS [28]. Moreover, the shape of the large-sized AS is flatter than the small particles, which affects the fluidity and mechanical strength of concrete [29]. Therefore, the AS with a maximum size of $4.75 \mathrm{~mm}$ was used for the aggregates, which was obtained from local fruit processing plants (Sichuan, China). After crushing, they were first washed to remove dust and other wastes, and then air-dry before surface treatment. The particle size distribution of the aggregate is shown in Fig. 1. The specific density of AS was $1.42 \mathrm{~g} / \mathrm{cm}^{3}$, the bulk density was $610 \mathrm{~kg} / \mathrm{m}^{3}$ and the 24 -h water absorption was $15.2 \%$. The AS and its microscopic image is shown in Fig. 2 . The results show that the AS is flaky, coarse with irregular edges, the inner concave surface shows a smooth texture, while the convex surface rough. Besides, many micropores are present on the surface, which results in the lightweight and high water absorption of the AS.

The sand was obtained from Guanghan town in Chengdu Plain, China, which was river sand. The specific density, bulk density and $24 \mathrm{~h}$ water absorption of sand were $2.58 \mathrm{~g} / \mathrm{cm}^{3}, 1569 \mathrm{~kg} / \mathrm{m}^{3}$ and $1.2 \%$, respectively. The fineness modulus of sand was 2.89, which is a medium grain sand according to GB/T14684-2011.

The water used was tap water, and a superplasticizer ( $\beta$-naphthalene sulfonic acid-formaldehyde condensate) was added in all mixes to improve the workability of fresh mixture. The dosage of the superplasticizer was $1 \mathrm{wt} \%$ of cement content.

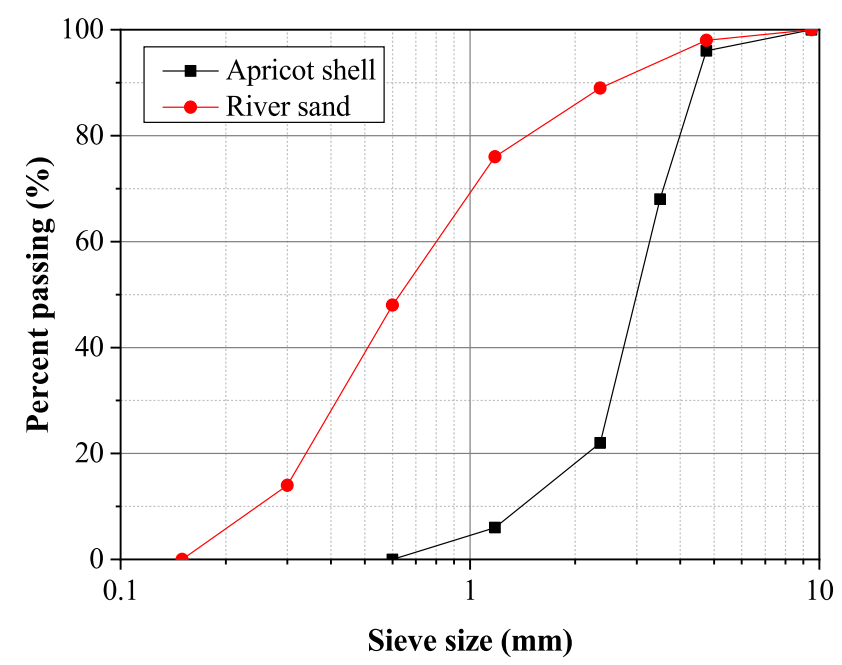

Fig. 1. Particle size distribution of apricot shell and river sand.

Table 1

Composition of cement (wt\%) [17].

\begin{tabular}{|c|c|c|c|c|c|c|c|c|c|c|}
\hline Oxides & $\mathrm{CaO}$ & $\mathrm{SiO}_{2}$ & $\mathrm{Al}_{2} \mathrm{O}_{3}$ & $\mathrm{Fe}_{2} \mathrm{O}_{3}$ & $\mathrm{SO}_{3}$ & $\mathrm{MgO}$ & $\mathrm{Na}_{2} \mathrm{O}$ & $\mathrm{K}_{2} \mathrm{O}$ & $\mathrm{Ti}_{2} \mathrm{O}$ & LOI \\
\hline Cement & 68.3 & 16.2 & 2.8 & 3.6 & 3.1 & 1.1 & 0.1 & 0.5 & 0.4 & 2.5 \\
\hline
\end{tabular}



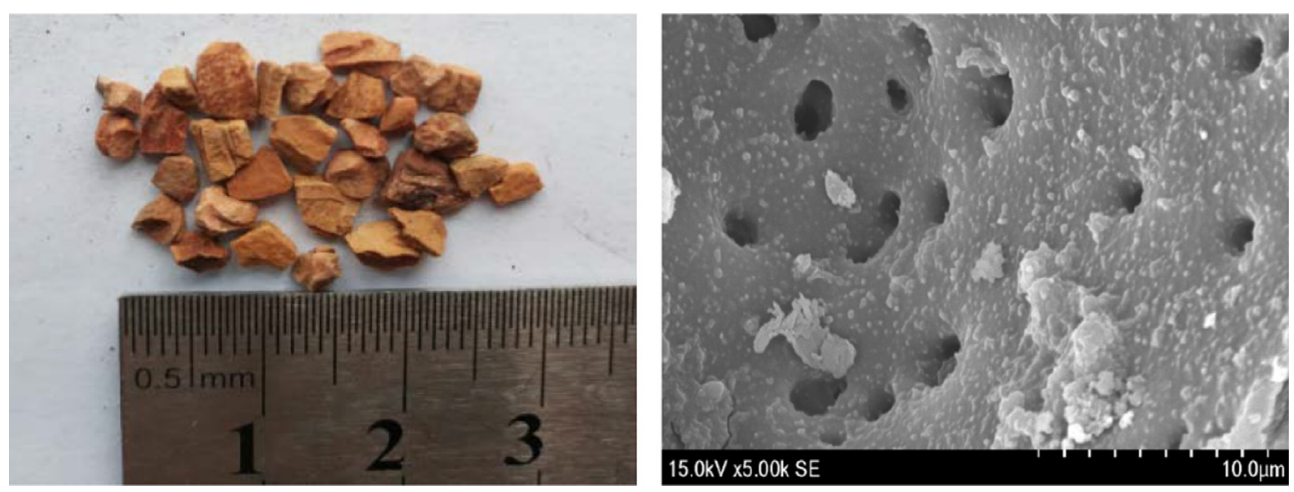

Fig. 2. Apricot shell and its microscopic image [11].

\subsection{Methods of treatment}

The schematic diagram of the surface treatment of AS is shown in Fig. 3. A total of five surface treatments were used for improving the surface properties of AS. The duration of AS treated with different treatments was $24 \mathrm{~h}$ at room temperature, and then the treated AS (except wood oil treatment) was removed from the solution. The AS surface was air dried prior to the application.

Cement solution (CS) treatment: The cement used to prepare the cement solution is the same as that used for the specimen preparation, that is, the Portland cement of Type I 42.5. The mass ratio of cement to water was 1:5. After the cement solution was prepared, AS was submerged in the solution for $24 \mathrm{~h}$. To uniformly disperse the cement in the solution, the upper solution was continuously stirred using a small electric mixer.

Waterproof agent (WP) treatment: AS was immersed in a $10 \%$ waterproof agent solution (Shanghai Xuanhong Waterproof Technology Co. Ltd., Shanghai, China). AS treated with the waterproof agent may reduce its water absorption, which is beneficial to reduce fungal growth and decay rates, ultimately improving the properties of AS [30].

Wood oil (WO) treatment: The surface of wood treated with wood oil can improve its antifungal decay and anti-corrosion properties, ultimately increasing the service life of wood [31]. In this study, the surface of AS was coated with wood oil (Anhui Dizhi Chemical Technology Co., Ltd., Anhui, China) with a brush, and then air dried at room temperature. The dosage of wood oil was $10 \%$ of AS by weight.

Sodium silicate (SS) treatment: AS was immersed in a sodium silicate (Tianjin Dingshengxin Chemical Industry Co., Ltd., Tianjin, China) solution with a concentra- tion of $120 \mathrm{~g} / \mathrm{L}$. Sodium silicate $\left(\mathrm{Na}_{2} \mathrm{O} \cdot n \mathrm{SiO}_{2}\right)$ is a liquid colloidal solution with cementation ability, which can react with carbon dioxide and harden in air, the precipitated silicic acid gel can block the capillary pores of the material, preventing the penetration of moisture. The reaction formula is [30]:

$$
\mathrm{Na}_{2} \mathrm{O} \cdot n \mathrm{SiO}_{2}+\mathrm{CO}_{2}+m \mathrm{H}_{2} \mathrm{O}=\mathrm{Na}_{2} \mathrm{CO}_{3}+n \mathrm{SiO}_{2} \cdot m \mathrm{H}_{2} \mathrm{O}
$$

White latex (WL) treatment: The white latex (Hefei Daochou Co., Ltd., Anhui, China) was diluted to a concentration of $12 \%$ by mixing with warm water. After that, the AS was poured into white latex solution and soaked for $24 \mathrm{~h}$.

\subsection{Specimen preparation and test method}

$450 \mathrm{~kg} / \mathrm{m}^{3}$ cement, $780 \mathrm{~kg} / \mathrm{m}^{3}$ sand, $330 \mathrm{~kg} / \mathrm{m}^{3}$ AS and 0.35 water-cement ratio were chosen the proportion of concrete, which referred to the technical specification for lightweight aggregate (JGJ-51-2002) [33] and the mix proportion of peach shell concrete [34]. AS without any surface treatment was also prepared for comparison purposes. The mixing methods of concrete are shown in Fig. 4. The wet mixing method was adopted for soaked aggregates because they have a saturated dry surface after soaking. The dry mixing method (JGJ-51-2002) was used for wood oil treated aggregates due to they have a dry surface. After mixing, the fresh concrete was poured into the mould and compacted on a vibrating table. Then the specimen surface was covered with a plastic film and stored in the laboratory. After $24 \mathrm{~h}$, the specimen was demoulded and cured in water until the test age.

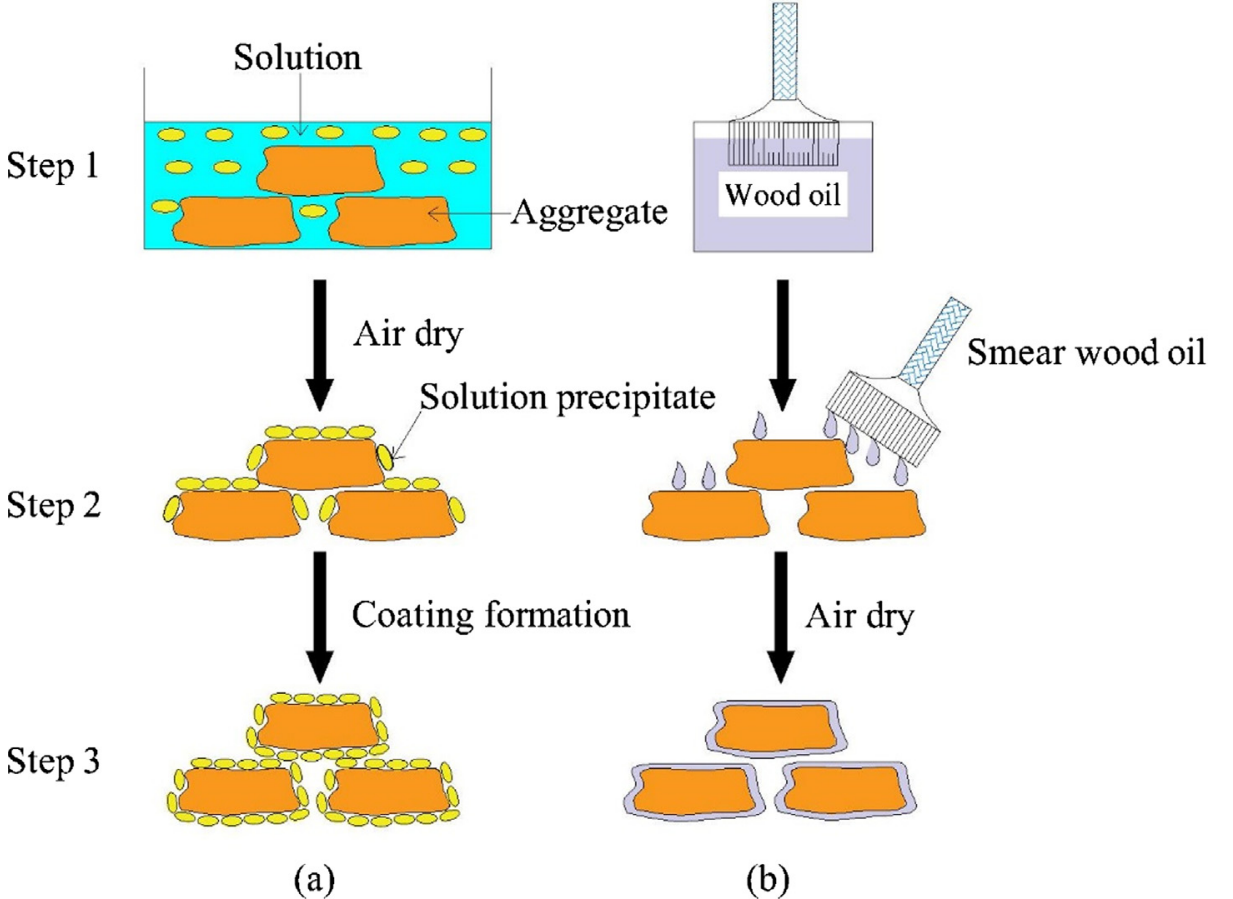

Fig. 3. Schematic diagram of the surface treatments of apricot shell (a) Soaking treatment and (b) Wood oil treatment. 


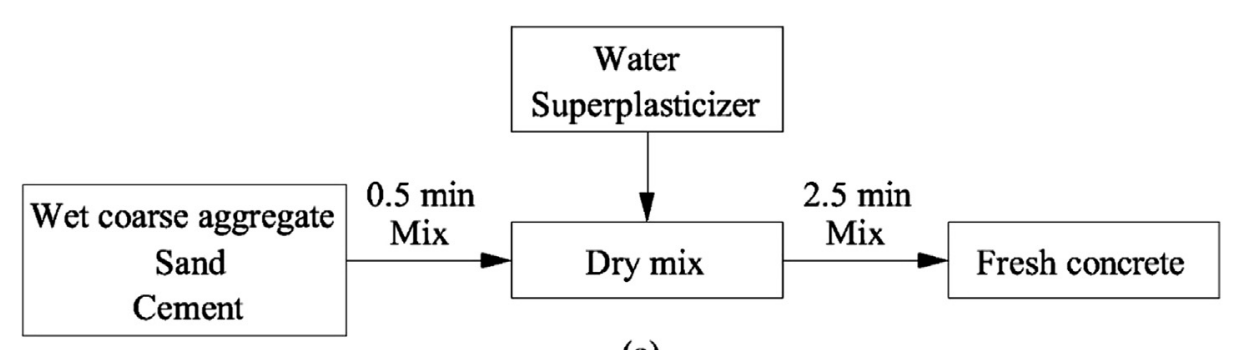

(a)

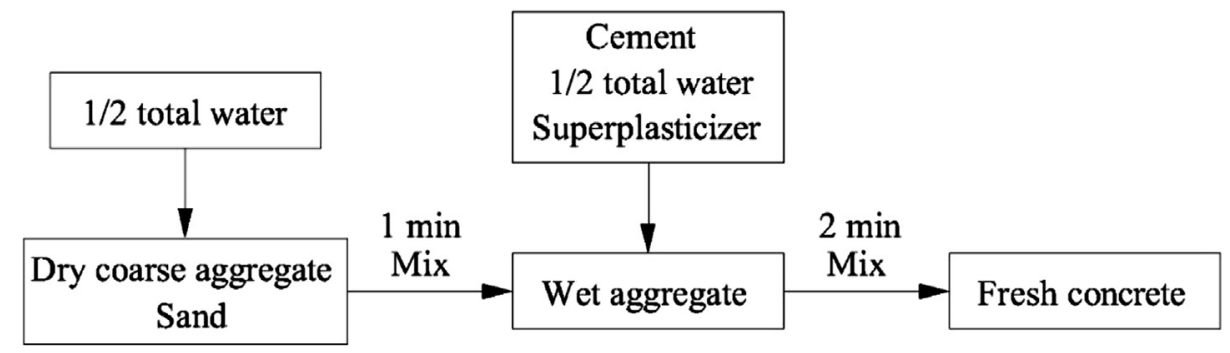

(b)

Fig. 4. Mixing methods of concrete (a) Soaked aggregates in solution and (b) Aggregates coated with wood oil.

The bulk crushing strength and water absorption of AS before and after treatment was determined according to EN13055-2:2004 and EN 1097-6, respectively. A total of 198 cube specimens $\left(100 \times 100 \times 100 \mathrm{~mm}^{3}\right)$ were used for density (ASTM C138/C138-14M), porosity and water absorption (ASTM C642-13), compressive strength and splitting tensile strength (GB/T 50080-2016), resistance to magnesium sulfate attack test (GB/T 50082-2009). The same batch of the cube specimen was used to measure density, water absorption and porosity. A total of 18 beams $\left(100 \times 100 \times 400 \mathrm{~mm}^{3}\right)$ and 18 cylinders $(\Phi 100 \times 200 \mathrm{~mm})$ specimens were used for the flexural strength and modulus of elasticity test (GB/T 50080-2016), respectively. A 4\% magnesium sulfate solution was used for sulfate resistance test, which was replaced once a month by the new magnesium sulfate solution to ensure the same concentration. The average value of the three tests was used for the result analysis.

\section{Results and discussion}

\subsection{Properties of the treated aggregates}

The surfaces of the apricot shell (AS) before and after treatment are shown in Fig. 5. The colour of AS treated with the waterproof agent (WP), white latex (WL) and coating the wood oil (WO) turned from pale yellow to light brown. After sodium silicate (SS) treatment, a dark brown color was observed on the AS surface. As shown in Table 2, the bulk crushing strength of AS treated with WO increased more than other treatments. This can be explained by a thicker oil film formed on the AS surface than other treatments [35]. The water absorption of WO treatment decreased by $9.2 \%$, compared to the untreated AS. Although WO can significantly improve the biodegradation properties [30] and reduce the water absorption, it is hydrophobic that may affect the bond between the treated aggregate and mortar.

The results also showed that all treatments slightly increased the mass of AS and decreased the water absorption. This is attributed to the precipitation of the solute and the formation of a thin film on the surface [36]. Although the surface treatment does not have a significant influence on the water absorption and strength of the single particles, it may affect the interface between the treated aggregate surface and the mortar [13]. When the cement was deposited on a smooth surface of the aggregate, it can increase the surface roughness and improve the mortar bond with the aggregate [37]. Moreover, the surface treatment such as SS treatment can also enhance the resistance against fungi attack of organic aggregates [24].

\subsection{Physical properties of concrete}

\subsubsection{Density}

The density of concrete is shown in Fig. 6. The WO treatment slightly decreased the density of concrete, while other treatments increased the density. The AS treated with wood oil had a minimum oven dry density of $1724 \mathrm{~kg} / \mathrm{m}^{3}$, which was reduced by $28 \%$, compared to normal density concrete of about $2400 \mathrm{~kg} / \mathrm{m}^{3}$. This because the WO is a hydrophobic material that may influence the bond between the AS and the mortar and increase the porosity of concrete [35]. The oven dry densities of all apricot shell bioconcrete (ASC) in this study were less than $2000 \mathrm{~kg} / \mathrm{m}^{3}$, which all within the range of lightweight concrete according to the EN Standard (EN206-1).

\subsubsection{Water absorption}

As shown in Fig. 7, the water absorption of ASC increased with time. The WO treatment increased the water absorption of concrete, while the other treatments slightly decreased the water absorption. The 24-h water absorption of WP treatment was $7.2 \%$, which was reduced by $8.9 \%$ compared to the untreated AS. This can be explained by the fact that the silicone waterproof agent precipitates on the capillary surface of the aggregate, which forms a water resistant layer [38]. Generally, the water absorption of concrete increases as the percentage of voids in the interfacial transition zone (ITZ) increases [39]. When the bond ability of the aggregate-mortar interface is weaker, the water more easily transports along the interface by diffusion or capillary action [40]. Liu et al. [41] reported that the addition of the waterproof agent in ordinary concrete significantly enhanced the impermeability and mechanical strength of concrete due to the formation of hydrated calcium silicate near the cracks, which blocked the cracks and capillaries of concrete. Therefore, the WP treatment is appropriate to reduce the water absorption of concrete.

\subsubsection{Porosity}

When external water enters the concrete through the open pores, the harmful ions dissolved in the water such as chloride, sulfate, magnesium will cause the dissolution of hydroxide and calcium ions, which results in the degradation of concrete [42]. The 


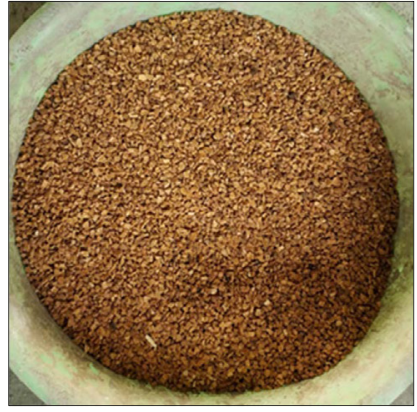

(a) No treatment

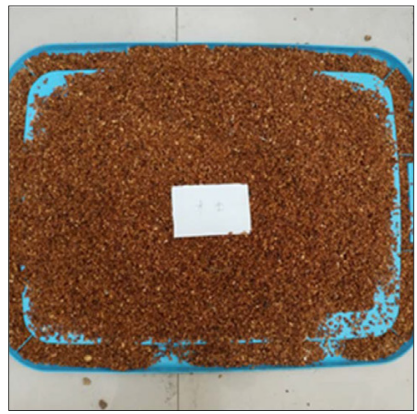

(d) Wood oil treatment

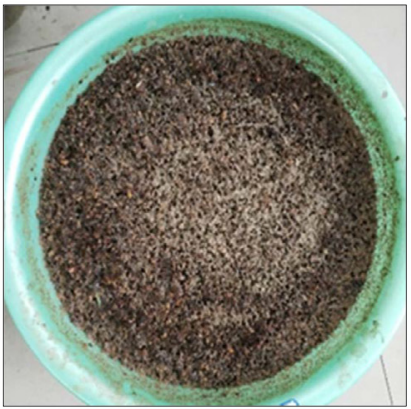

(b) Cement treatment

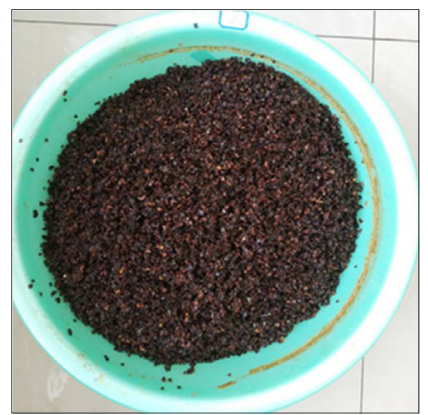

(e) Sodium silicate treatment

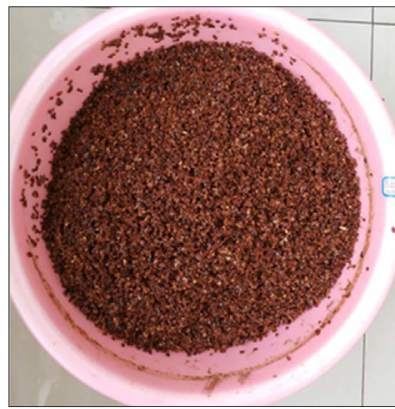

(c) Waterproof agent treatment

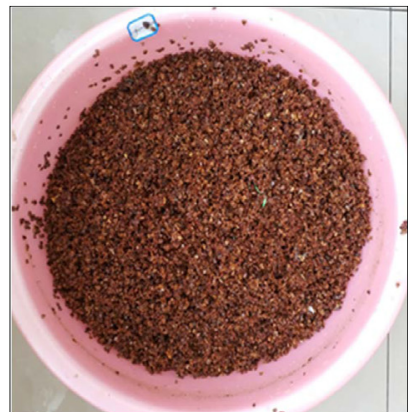

(f) White latex treatment

Fig. 5. Apricot shell surface before and after treatment.

Table 2

Properties of the treated apricot shell.

\begin{tabular}{|c|c|c|c|c|}
\hline Mix code & Treatment method & Strength ratio before and after treatment & Mass ratio before and after treatment & Water absorption capacity at $24 \mathrm{~h}(\%)$ \\
\hline $\mathrm{N}$ & No treatment & 1 & 1 & 15.2 \\
\hline CS & Cement solution & 1.012 & 1.023 & 14.9 \\
\hline WP & Waterproofing agent solution & 1.009 & 1.011 & 14.2 \\
\hline WO & Wood oil & 1.018 & 1.017 & 13.8 \\
\hline SS & Sodium silicate solution & 1.006 & 1.014 & 14.8 \\
\hline WL & White latex solution & 1.002 & 1.009 & 15.0 \\
\hline
\end{tabular}

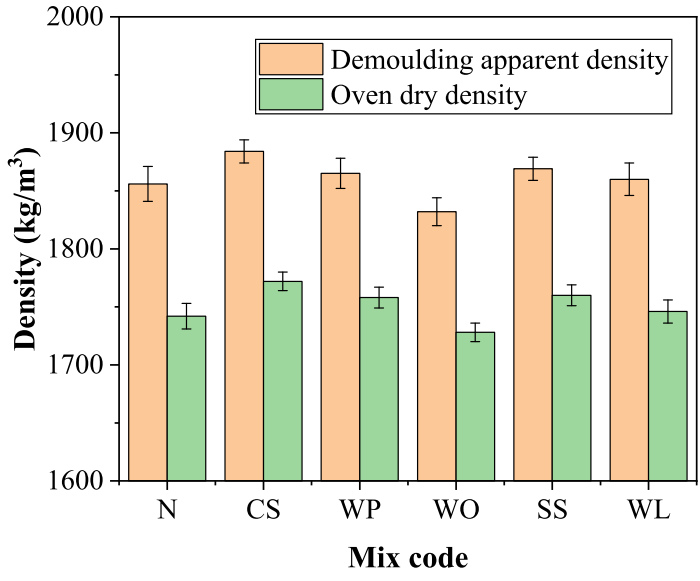

Fig. 6. Density of concrete.

porosity of concrete is shown in Fig. 8. Similar to the water absorption, the WO treatment slightly increased the porosity of ASC due to the presence of the hydrophobic oil film. However, the other treatments slightly reduced the porosity, especially for the CS

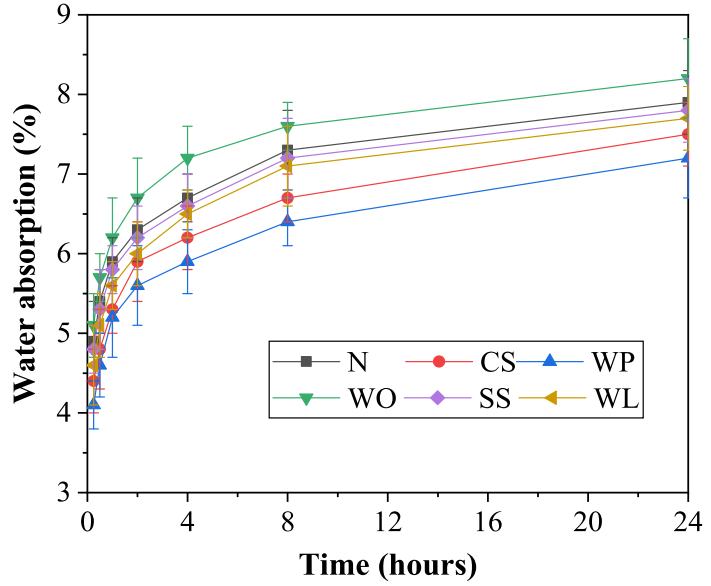

Fig. 7. Water absorption of concrete.

and WP treatment. This may be attributed to the increase of bond capacity and interface strength of the treated aggregate by coating with waterproof agent [43] and cement paste [37]. 


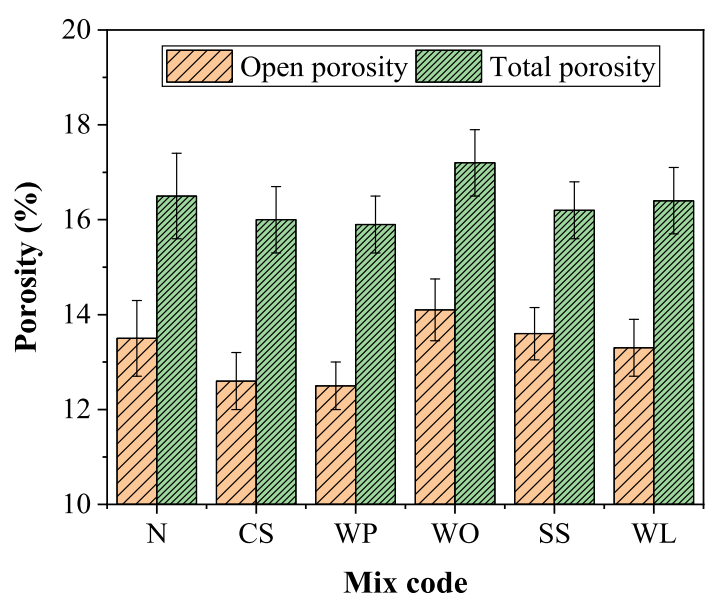

Fig. 8. Porosity of concrete.

\subsection{Mechanical properties}

\subsubsection{Compressive strength}

The compressive strength development of concrete is presented in Fig. 9. The results showed that the WP and CS treatments increased the compressive strength of ASC at all curing age and the 28-day compressive strength increased by $9.3 \%$ and $8.2 \%$, respectively, compared to the untreated AS. The WO treatment decreased the compressive strength at 28 days by $13.2 \%$. This indicated that although the WO treatment could significantly reduce the water absorption of the AS aggregate and improve its decay potential, the treatment of the AS with wood oil increased the porosity of concrete due to the presence of hydrophobic oil film $[22,35]$. Previous studies $[24,44]$ reported that the mechanical properties of wood treated with sodium silicate were enhanced because the ettringite was formed on the surface of the treated wood due to the presence of sodium. In this study, the SS treatment slightly improved the compressive strength of concrete. The addition of latex in pervious concrete can reduce the permeability of pervious concrete and increase mechanical strength due to the formation of a latex network structure [32]. However, the WL treatment had a negligible effect on the compressive strength of ASC.

Generally, the weak bond between the organic aggregate and the mortar is one of the main limiting factors for using the organic aggregates in concrete [13,21,45]. As shown in Fig. 10, the obvious cracks were observed at the interface between the untreated AS

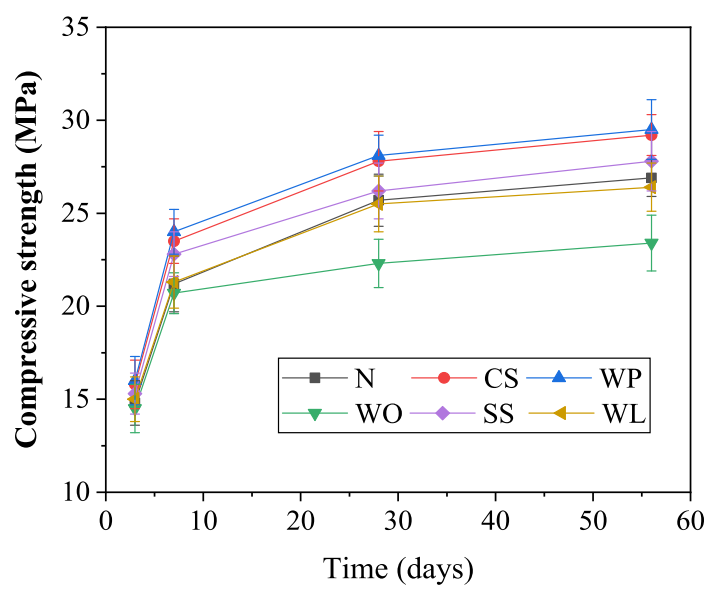

Fig. 9. Development of compressive strength of the tested concretes. and the mortar, and the microporous structure on the untreated AS surface was visible. However, when the AS aggregate was treated with waterproof agent, it had better surface characteristics and a good bond to the mortar interface, and no micropores were observed on the surface. Therefore, the WP treatment is a good method to improve the surface characteristics of the AS aggregate and enhance the adhesion to the mortar.

\subsubsection{Splitting tensile and flexural strength}

As shown in Table 3, the WO treatment reduced the splitting tensile strength and flexural strength of ASC, and other treatments increased the splitting tensile and flexural strength. The splitting tensile strength and flexural strength of the WP treatment increased by $16.3 \%$ and $15.1 \%$, respectively, compared to the untreated AS. This may be attributed to the fact that the waterproof agent promotes the hydration of the unhydrated cement and produces more hydration products, which reduces the porosity and improves the compactness of concrete [46].

The relationship between compressive strength and splitting tensile strength and flexural strength are shown in Fig. 11. Compared to concrete made of coconut shell [21] and oil palm shell [45], at the same splitting tensile and flexural strength condition, the compressive strength of ASC was better than that of coconut shell concrete and lower than that of oil palm shell concrete. The WP treatment had the highest splitting tensile strength and flexural strength, which meets the requirement of the minimum splitting strength of $2 \mathrm{MPa}$ for structural lightweight concrete [47], and can be used as the aggregates for the production of structural lightweight concrete.

\subsubsection{Modulus of elasticity}

The modulus of elasticity of ASC ranged between 9.7 GPa and 12.4 GPa. Compared to the untreated AS, the modulus of elasticity of the WP and CS treatments improved by $19.2 \%$ and $16.3 \%$, respectively. The WO treatment reduced the modulus of elasticity, the SS and WL treatments had a negligible influence on the modulus of elasticity. The improvement in the bond between the aggregate and the mortar is beneficial for the modulus of elasticity [48]. The CEB/FIP manual specifies that the modulus of elasticity of lightweight concrete is usually between $10 \mathrm{GPa}$ and $24 \mathrm{GPa}$ [49]. The modulus of elasticity of ASC is within the range of modulus of elasticity of lightweight concrete, except for the WO treatment.

\subsection{Resistance to magnesium sulfate attack}

\subsubsection{Weight loss}

The change in the weight loss of ASC exposed by magnesium sulfate solution is shown in Fig. 12. The results indicated that the weight of concrete decreased over time, and the WP and CS treatments improved the resistance to magnesium sulfate of concrete and reduced the weight loss of concrete. The weight loss of the WP and CS treatments after sulfate attack for 180 days was $0.83 \%$ and $0.8 \%$, respectively, and the mass loss was reduced by $7.8 \%$ and $11.1 \%$, respectively, compared to the untreated AS. This may be attributed to the WP and CS treatments that reduce the porosity of concrete because of the block of the capillary pores, which reduces the uptake of water [50]. The linseed oil as a water repellent was added to the mortar, which increased the resistance to freeze-thaw of the mortar because of the presence of large spherical pores, which hindered the development of cracks [51]. However, the weight loss of the WO treatment after the sulfate attack for 180 days was $0.92 \%$, which reduced the resistance to magnesium sulfate of concrete because the oil film on the AS surface increased the porosity of concrete. 

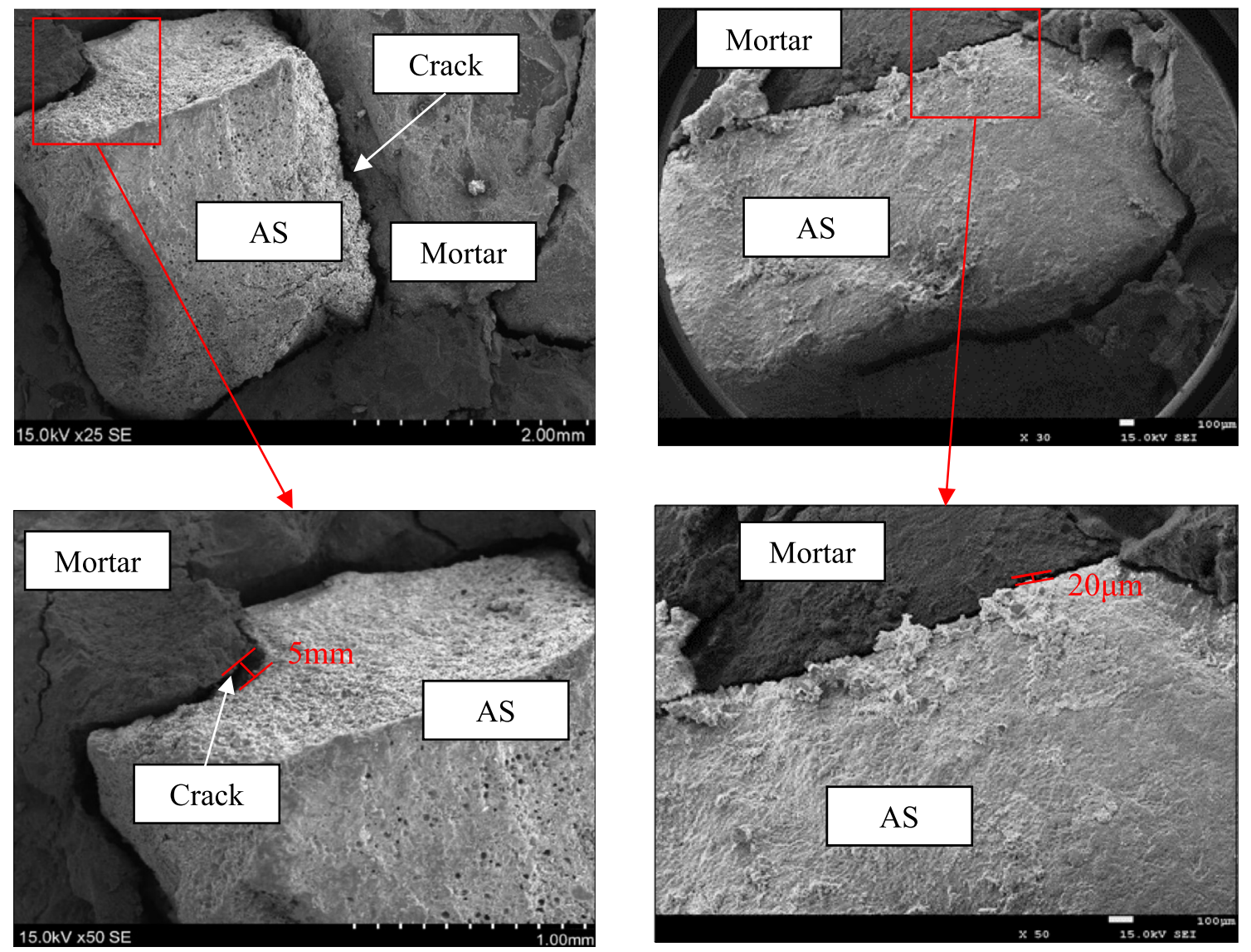

Fig. 10. Microscope image of concrete containing untreated (left) [17] and treated with waterproof agent (right) aggregate.

Table 3

Splitting tensile and flexural strengths and modulus of elasticity of concrete.

\begin{tabular}{llll}
\hline $\begin{array}{l}\text { Mix } \\
\text { code }\end{array}$ & $\begin{array}{l}\text { Splitting tensile } \\
\text { strength }(\mathrm{MPa})\end{array}$ & $\begin{array}{l}\text { Flexural strength } \\
(\mathrm{MPa})\end{array}$ & $\begin{array}{l}\text { Modulus of } \\
\text { elasticity }(\mathrm{GPa})\end{array}$ \\
\hline N & $2.21 \pm 0.14$ & $3.65 \pm 0.22$ & $10.4 \pm 0.4$ \\
CS & $2.43 \pm 0.15$ & $3.97 \pm 0.20$ & $12.1 \pm 0.5$ \\
WP & $2.57 \pm 0.17$ & $4.20 \pm 0.24$ & $12.4 \pm 0.3$ \\
WO & $1.91 \pm 0.20$ & $3.24 \pm 0.25$ & $9.7 \pm 0.5$ \\
SS & $2.31 \pm 0.16$ & $3.82 \pm 0.23$ & $10.6 \pm 0.4$ \\
WL & $2.30 \pm 0.13$ & $3.72 \pm 0.29$ & $10.3 \pm 0.3$ \\
\hline
\end{tabular}

a)

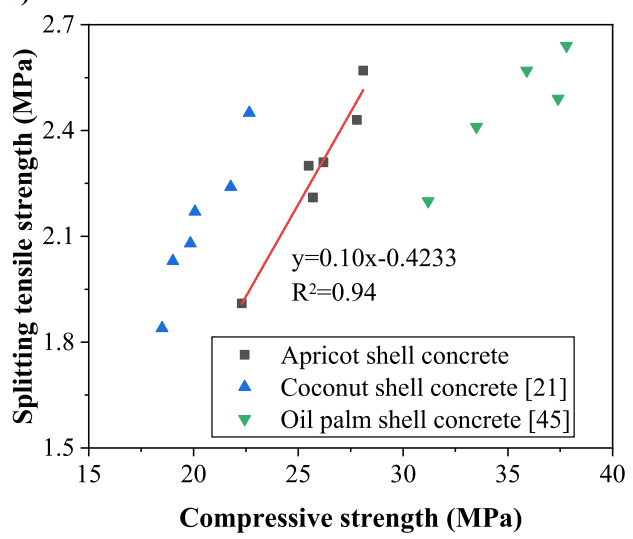

\subsubsection{Compressive strength loss}

As shown in Fig. 13, the compressive strength of ASC gradually decreased over time and the WO treatment had the highest compressive strength loss after sulfate attack for 180 days, which was decreased by $33.7 \%$ compared to the untreated AS. This may be attributed to the fact that porosity is one of the main factor influence the mechanical strength and durability of concrete [52]. The WO treatment increased the porosity of concrete, which led to an increase in the compressive loss of concrete because of the forma-

b)

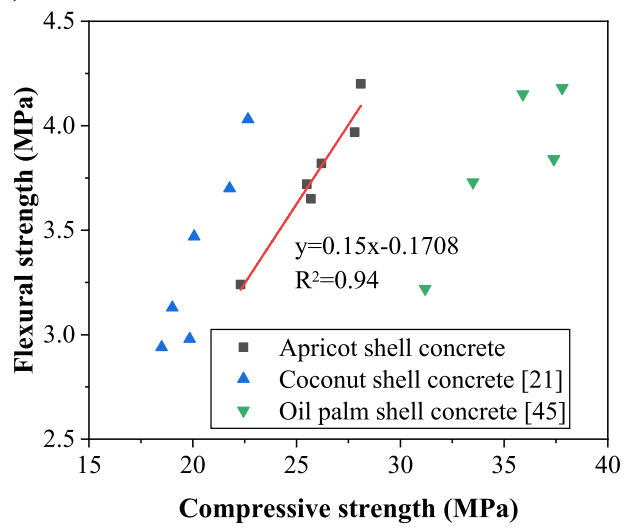

Fig. 11. Relationship between compressive strength and splitting tensile and flexural strength. 
a)

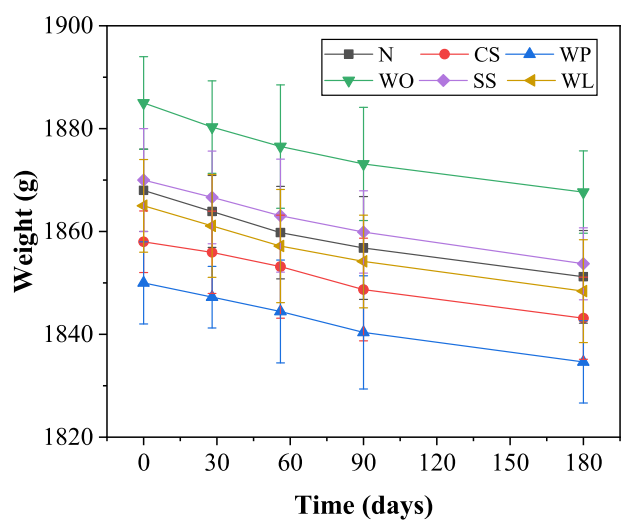

b)

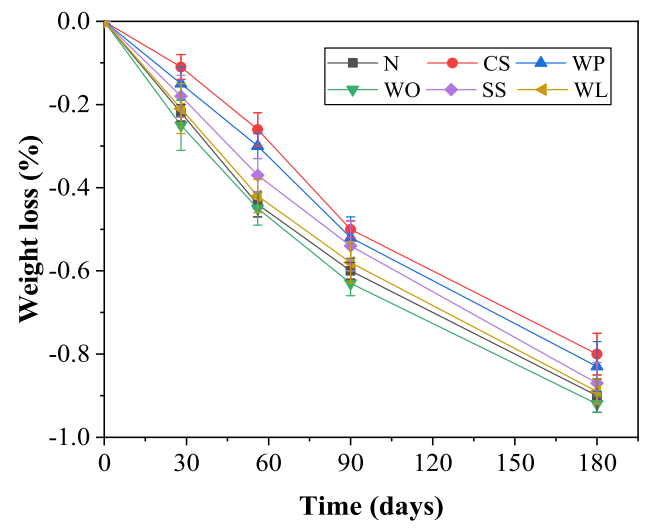

Fig. 12. Weight loss of specimens exposed by magnesium sulfate solution.
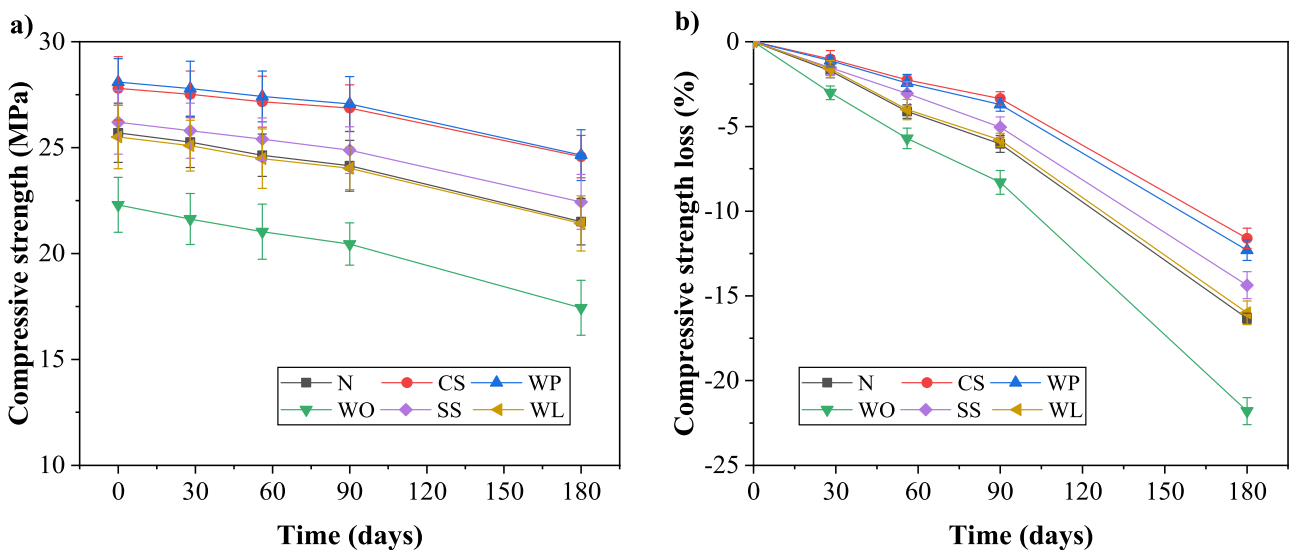

Fig. 13. Compressive strength loss of specimens exposed by magnesium sulfate solution.

tion of thaumasite and gypsum caused by magnesium sulfate attack [53]. The weight loss and compressive strength loss of coconut shell concrete after magnesium sulfate attack for 120 days were $1.3 \%$ and $19.8 \%$, respectively [21]. The compressive strength loss of the WP and CS treatments were $12.3 \%$ and $11.6 \%$, which was decreased by $24.5 \%$ and $28.8 \%$, respectively, compared to the untreated AS. Generally, the improvement in the adhesion of the interface between the treated aggregate and the mortar [46], reduces the porosity of concrete and the amount of deleterious ions entering the interior of concrete, increasing the chemical resistance of concrete [54].

The relationship between weight loss and compressive strength loss is shown in Fig. 14. The results showed that the compressive strength loss of ASC increased with the increase in weight loss. Compared to the untreated AS, the CS and WP treatment had a lower slope value, while the WO treatment had a higher slope value. There is no significant difference in the slope value of the SS and WL treatments. This indicated that the compressive strength loss of the WL and CS treatments was lower under the same mass loss conditions, while the compressive strength loss of the WO treatment was greater, compared to the untreated AS. The WP and CS treatments can improve the resistance to magnesium sulfate of ASC.

When concrete is exposed to a chemical solution, cracks or voids appear at the aggregate-mortar interface and the surface of

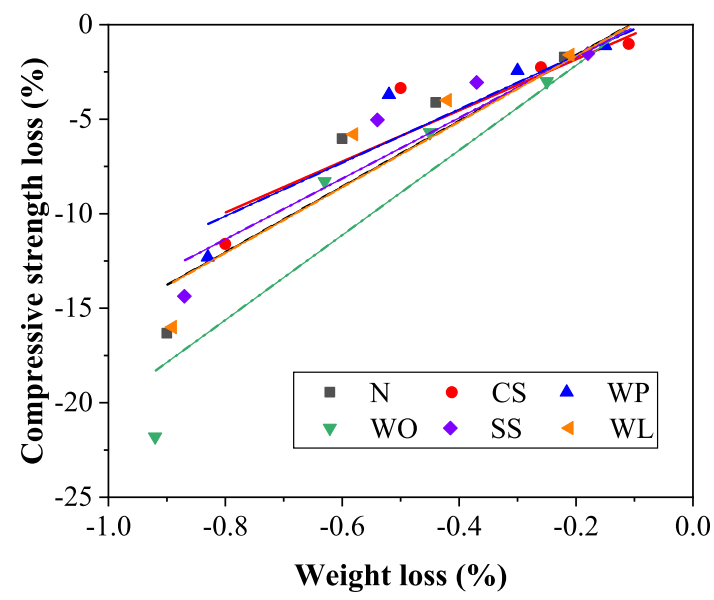

Fig. 14. Relationship between weight loss and compressive strength loss.

the mortar, leading to performance degradation of concrete [36,55]. As shown in Fig. 15, many microscopic cracks appeared on the mortar surface of ASC after immersion in magnesium sulfate solution for 180 days, which caused a reduction in the compressive strength. 

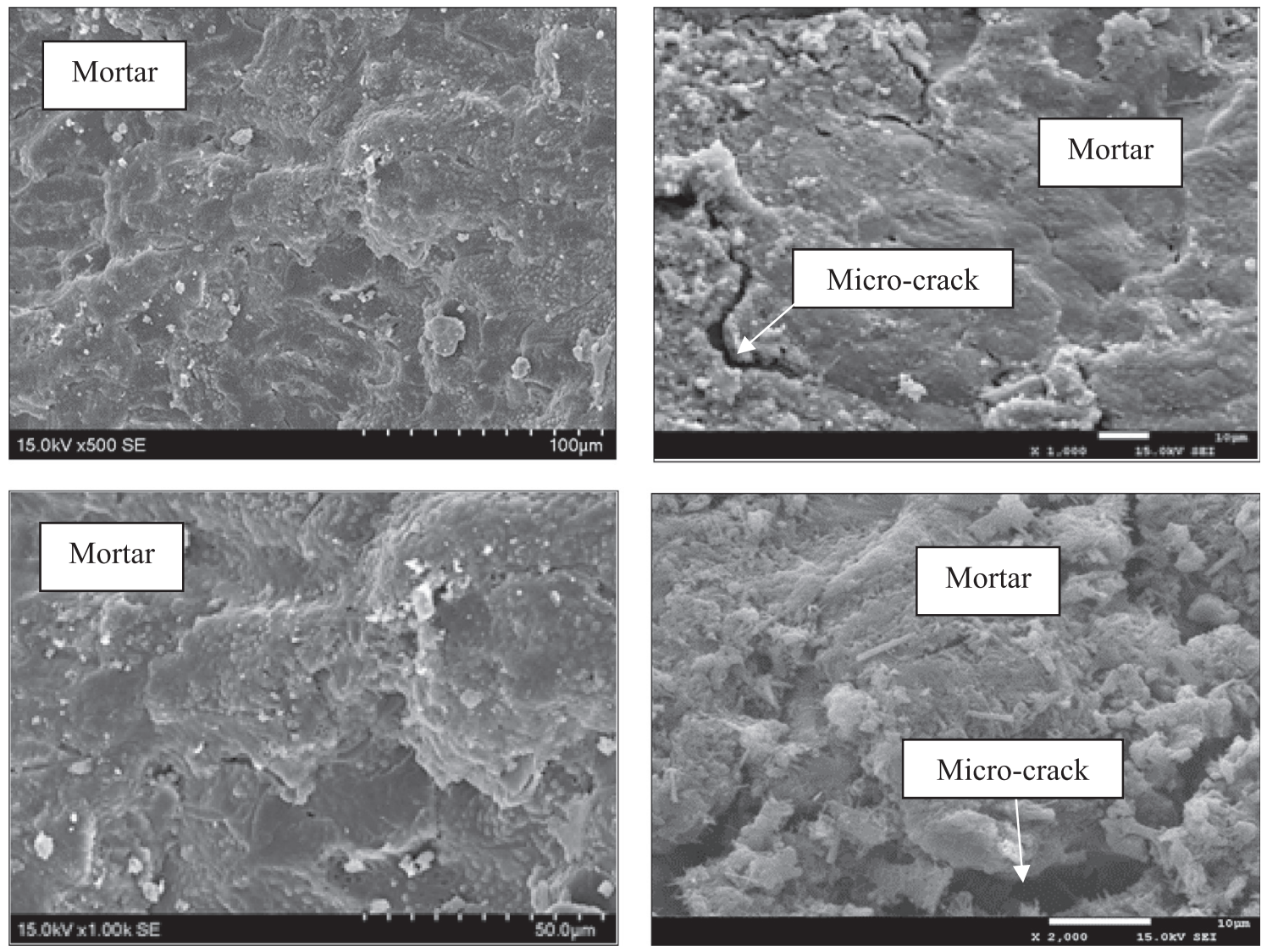

Fig. 15. Microscope images of concrete before (left) and after (right) immersion in magnesium sulfate solution for 180 days.

\section{Conclusions}

In this study, apricot shell (AS) treated with different surface treatments were used as the aggregates for the production of structural lightweight concrete. Cement solution (CS), waterproof agent (WP), wood oil (WO), sodium silicate (SS) and white latex (WL) were used to treat the AS aggregate. The physical and mechanical properties and the long term resistance to magnesium sulfate attack of apricot shell based lightweight bio-concrete were investigated. The following conclusions can be obtained:

1. The AS is porous and lightweight. The WO treatment and other treatments increase the strength and the mass of the AS and reduce the water absorption. The water absorption of the AS treated with wood oil reduces by $9.2 \%$, compared to the untreated AS.

2. The WO treatment decreases the density and increases the porosity and water absorption of concrete. While other treatments slightly increase the density and decrease the porosity and water absorption of concrete, especially for the WP treatment. The 24-h water absorption of WP treatment is $7.2 \%$, which reduced by $8.9 \%$, compared to the untreated AS.

3. The WP and CS treatments significantly improve the compressive strength of apricot shell bio-concrete (ASC) at all curing age, and the 28-day compressive strength increases by $9.3 \%$ and $8.2 \%$, respectively, compared to the untreated AS. The WO treatment decreases the compressive strength by $13.2 \%$ at 28 days. The SS treatment slightly enhances the compressive strength. However, the use of WL treated AS has a negligible influence on the compressive strength of concrete.

4. The WO treatment reduces the splitting tensile strength and flexural strength of ASC, and other treatments increase the splitting tensile strength and flexural strength. The splitting tensile strength and flexural strength of the WP treatment increase by $16.3 \%$ and $15.1 \%$, respectively, compared to the untreated AS. The AS treated with the waterproof agent is recommended for the production of structural lightweight concrete.

5. Compared to the untreated AS, the modulus of elasticity of the WP and CS treatments improves by $19.2 \%$ and $16.3 \%$, respectively. The WO treatment decreases the modulus of elasticity, the SS and WL treatments have a negligible influence on the modulus of elasticity.

6. The WP and CS treatments improve the resistance to magnesium sulfate. The weight loss and compressive strength loss of the concrete with WP and CS treatments after sulfate attack for 180 days are reduced by $7.8 \%$ and $11.1 \%, 24.5 \%$ and $28.8 \%$, respectively, compared to the untreated AS. However, the WO treatment reduces the resistance to magnesium sulfate attack of concrete.

\section{Declaration of Competing Interest}

The authors declare that they have no known competing financial interests or personal relationships that could have appeared to influence the work reported in this paper.

\section{Acknowledgements}

This work was funded by the Graduate Student's Research and Innovation Fund of Sichuan University (Grant No. 2018YJSY091), and the Key Laboratory of Geological Hazards Mitigation for Mountainous Highway and Waterway, Chongqing Municipal Education 
Commission Chongqing Jiaotong University (Grant No. kfxm201801), the China Scholarship Council (CSC) Fund (Grant No. 201806240037) and Eindhoven University of Technology. We also would like to thank the Analytical \& Testing Center of Sichuan University for the assistance with microscopic analysis and testing of concrete.

\section{References}

[1] L.B. Wang, Progress of exploitation and utilization research of wild apricot, J. Zhejiang For. Sci. Technol. 28 (6) (2008) 76-80.

[2] National Forestry and Grassland Administration \& National Park Administration, China Forestry Database, Forest Industrial Development, 2014. http://124.205.185.8/lysjk/indexJump.do?url=view/moudle/ searchData/firstStage\&key=\%E5\%8E\%86\%E5\%B9\%B4\%E7\%BB\%9F\%E8\%AE\%A1\% E6\%95\%B0\%E6\%8D\%AE\%E5\%BA\%93.

[3] National Forestry and Grassland Administration \& National Park Administration, Local articles - Inner Mongolia - apricot, 2015. http:// www.forestry.gov.cn/main/437/content-780166.html.

[4] S. Yüksel, R. Orhan, The removal of $\mathrm{Cr}$ (VI) from aqueous solution by activated carbon prepared from apricot, peach stone and almond shell mixture in a fixed-bed column, Arab. J. Sci. Eng. (2018) 1-13.

[5] A. El-Saharty, S.N. Mahmoud, A.H. Manjood, A.A.H. Nassar, A.M. Ahmed, Effect of apricot stone activated carbon adsorbent on the removal of toxic heavy metals ions from aqueous solutions, Int. J. Ecotoxicol. Ecobiol. 3 (2) (2018) 51.

[6] M. Buyukada, E. Aydogmus, Utilization of apricot seed in (co-) combustion of lignite coal blends: numeric optimization, empirical modeling and uncertainty estimation, Fuel 216 (2018) 190-198.

[7] B. Tavakoli-Hosseinabady, P. Ziarati, E. Ballali, K. Umachandran, Detoxification of heavy metals from leafy edible vegetables by agricultural waste: apricot pit shell, J. Environ. Anal. Toxicol. 8 (548) (2018). 2161-0525.

[8] A. Akkaoui, S. Caré, M. Vandamme, Experimental and micromechanical analysis of the elastic properties of wood-aggregate concrete, Constr. Build. Mater. 134 (2017) 346-357.

[9] P. Shafigh, M.Z. Jumaat, H. Mahmud, Oil palm shell as a lightweight aggregate for production high strength lightweight concrete, Constr. Build. Mater. 25 (4) (2011) 1848-1853.

[10] K.H. Mo, U.J. Alengaram, M.Z. Jumaat, S.P. Yap, S.C. Lee, Green concrete partially comprised of farming waste residues: a review, J. Cleaner Prod. 117 (2016) 122-138.

[11] F. Wu, C.W. Liu, W. Sun, L.W. Zhang, Y.J. Ma, Mechanical and creep properties of concrete containing apricot shell lightweight aggregate, KSCE J. Civ. Eng. (2019) 1-10.

[12] S. Yildiz, M. Emiroğlu, O. Atalar, Apricot pip shells used as aggregate replacement, J. Civ. Eng. Manage. 18 (3) (2012) 318-322.

[13] C.C. Thong, C.L.T. Delsye, K.N. Chee, Durability characteristics of polyvinyl alcohol-treated oil palm shell concrete, J. Mater. Civ. Eng. 29 (10) (2017) 04017200.

[14] F. Wu, C.W. Liu, W. Sun, L.W. Zhang, Mechanical properties of bio-based concrete containing blended peach shell and apricot shell waste, Mater. Tehnol. 52 (5) (2018) 645-651.

[15] J.W. Jing, Comparison of preservation between wood based composites and lumber, China Forest. Sci. Technol. 4 (2009) 1-5.

[16] G.D. De La Grée, Q.L. Yu, H.J.H. Brouwers, Assessing the effect of CaSO4 content on the hydration kinetics, microstructure and mechanical properties of cements containing sugars, Constr. Build. Mater. 143 (2017) 48-60.

[17] F. Wu, C.W. Liu, L.W. Zhang, Y.H. Lu, Y.J. Ma, Comparative study of carbonized peach shell and carbonized apricot shell to improve the performance of lightweight concrete, Constr. Build. Mater. 188 (2018) 758-771.

[18] H.T. Su, Y.J. Zhang, L. Liu, Wood preservation plants in China: problems and suggestions, China Wood Indus. 21 (6) (2007) 31-33.

[19] M.K. Yew, H.B. Mahmud, B.C. Ang, M.C. Yew, Effects of heat treatment on oil palm shell coarse aggregates for high strength lightweight concrete, Mater. Des. (1980-2015) 1 (54) (2014) 702-707.

[20] R.H. Kupaei, U.J. Alengaram, M.Z. Jumaat, The effect of different parameters on the development of compressive strength of oil palm shell geopolymer concrete, Sci. World J. (2014).

[21] J.J. Regin, P. Vincent, C. Ganapathy, Effect of mineral admixtures on mechanical properties and chemical resistance of lightweight coconut shell concrete, Arab. J. Sci. Eng. 42 (3) (2017) 957-971.

[22] M. Bederina, M. Gotteicha, B. Belhadj, R.M. Dheily, M.M. Khenfer, M. Queneudec, Drying shrinkage studies of wood sand concrete-Effect of different wood treatments, Constr. Build. Mater. 36 (2012) 1066-1075.

[23] F.L. Sun, N.K. Prosper, H.P. Wu, J.J. Qian, X.H. Yang, J. Rao, M. Guo, A review on the development of wood and bamboo preservation, J. Forest. Eng. 2 (5) (2017) $1-8$.

[24] P. Coatanlem, R. Jauberthie, F. Rendell, Lightweight wood chipping concrete durability, Constr. Build. Mater. 20 (9) (2006) 776-781.

[25] H.C. Chu, X.J. Lu, Y. Zhang, Z.Q. Wang, Status and prospects of research on reducing the water absorption of foamed concrete, Bull. Chin. Ceram. Soc. 9 (35) (2016) 2852-2859.
[26] V. Spaeth, A.D. Tegguer, Improvement of recycled concrete aggregate properties by polymer treatments, Int. J. Sustainable Built Environ. 2 (2) (2013) 143-152.

[27] G.H. Zhang, J.B. Guo, C.J. Yu, J.W. Wang, Effect of compound repelling agent on salt frost resistance of concrete, Bull. Chin. Ceram. Soc. 7 (36) (2017) 2358 2363.

[28] X.Y. Tian, Y.S. Dong, J.N. Yang, C.M. Zhang, Effects of particle size and water content of raw materials on properties of activated carbon prepared by H3PO4 activation, Chem. Indus. For. Prod. 36 (6) (2016) 93-99.

[29] M. Geiker, M. Brandl, L. Thrane, L. Nielsen, On the effect of coarse aggregate fraction and shape on the rheological properties of self-compacting concrete Cem. Concr. Aggregates 24 (1) (2002) 3-6.

[30] G.B. Zhang, Z.Q. Zhong, Y. Yao, C.H. Yang, Building Materials, China Electric Power Press, Beijing, 2010.

[31] M.L. Jiang, Current status of research and development of new wood preservation technology, China Wood Indus. 20 (2) (2006) 23-25.

[32] B. Huang, H. Wu, X. Shu, E.G. Burdette, Laboratory evaluation of permeability and strength of polymer-modified pervious concrete, Constr. Build. Mater. 24 (5) (2010) 818-823.

[33] China Industry Standard. Technical specification for lightweight aggregate concrete. JGJ-51-2002, Beijing, 2002.

[34] F. Wu, C.W. Liu, Z.F. Diao, B. Feng, W. Sun, X.L. Li, S. Zhao, Improvement of mechanical properties in polypropylene-and glass-fibre-reinforced peach shell lightweight concrete, Adv. Mater. Sci. Eng. (2018).

[35] M. Tsujino, T. Noguchi, M. Tamura, M. Kanematsu, I. Maruyama, Application of conventionally recycled coarse aggregate to concrete structure by surface modification treatment, J. Adv. Concr. Technol. 5 (1) (2007) 13-25.

[36] Y.B. Traore, A. Messan, K. Hannawi, J. Gerard, W. Prince, F. Tsobnang, Effect of oil palm shell treatment on the physical and mechanical properties of lightweight concrete, Constr. Build. Mater. 161 (2018) 452-460.

[37] C.H. Lee, J.C. Du, D.H. Shen, Evaluation of pre-coated recycled concrete aggregate for hot mix asphalt, Constr. Build. Mater. 28 (1) (2012) 66-71.

[38] D.A. Kagi, K.B. Ren, Reduction of water absorption in silicate treated concrete by post-treatment with cationic surfactants, Build. Environ. 30 (2) (1995) 237 243.

[39] P. Shafigh, H.B. Mahmud, M.Z.B. Jumaat, R. Ahmmad, S. Bahri, Structural lightweight aggregate concrete using two types of waste from the palm oil industry as aggregate, J. Cleaner Prod. 80 (2014) 187-196.

[40] M. Frigione, M.A. Aiello, C. Naddeo, Water effects on the bond strength of concrete/concrete adhesive joints, construction and building materials, Constr. Build. Mater. 20 (10) (2006) 957-970.

[41] H. Liu, S. Yin, T. Li, Z. Wen, H. Shi, J. Liu, Experimental research of cementitious capillary crystalline waterproofing material applied to metro engineering concrete, Concrete 4 (2007) 40-43.

[42] E. Rozière, A. Loukili, R. El Hachem, F. Grondin, Durability of concrete exposed to leaching and external sulphate attacks, Cem. Concr. Res. 39 (12) (2009) 1188-1198.

[43] Y.Y. Hu, T.S. He, J.H. Li, Influence of durability to modified organosilicon waterproof agent on concrete, Sichuan Build. Sci. 3 (36) (2010) 214-216.

[44] J.L. Pehanich, P.R. Blankenhorn, M.R. Silsbee, Wood fiber surface treatment level effects on selected mechanical properties of wood fiber-cement composites, Cem. Concr. Res. 34 (1) (2004) 59-65.

[45] M.A. Mannan, C. Ganapathy, Engineering properties of concrete with oil palm shell as coarse aggregate, Constr. Build. Mater. 16 (1) (2002) 29-34.

[46] D. Wang, Y. Zhang, C. Zeng, X. Liu, Microscopic analysis and study on performance of cementitious capillary crystalline waterproofing agents, New Build. Mater. 2 (2008) 77-80.

[47] N.U. Kockal, T. Ozturan, Strength and elastic properties of structural lightweight concretes, Mater. Des. 32 (2011) 2396-2403.

[48] G.F. Kheder, S.A. Al-Windawi, Variation in mechanical properties of natural and recycled aggregate concrete as related to the strength of their binding mortar, Mater. Struct. 38 (7) (2005) 701-709.

[49] A. Short, Lightweight Aggregate Concrete: CEB/FIP Manual of Design and Technology, Construction Press, 1977.

[50] A. Izaguirre, J. Lanas, J.I. Alvarez, Effect of water-repellent admixtures on the behaviour of aerial lime-based mortars, Cem. Concr. Res. 39 (11) (2009) 10951104.

[51] C. Nunes, Z. Slížková, Freezing and thawing resistance of aerial lime mortar with metakaolin and a traditional water-repellent admixture, Constr. Build. Mater. 114 (2016) 896-905.

[52] M.K. Yew, M.C. Yew, L.H. Saw, S.K. Lim, J.H. Beh, T.C. Ng, Enhancement of durability properties and drying shrinkage of heat-treated oil palm shell species high-strength lightweight concrete, Nanosci. Nanotechnol. 1 (1) (2018) 1.

53] S.A. Hartshorn, J.H. Sharp, R.N. Swamy, The thaumasite form of sulfate attack in Portland-limestone cement mortars stored in magnesium sulfate solution, Cem. Concr. Compos. 24 (3-4) (2002) 351-359.

[54] K. Sotiriadis, E. Nikolopoulou, S. Tsivilis, A. Pavlou, E. Chaniotakis, R.N. Swamy, The effect of chlorides on the thaumasite form of sulfate attack of limestone cement concrete containing mineral admixtures at low temperature, Construct. Build. Mater. 43 (2013) 156-164.

[55] Y. Senhadji, G. Escadeillas, M. Mouli, H. Khelafi, Influence of natural pozzolan, silica fume and limestone fine on strength, acid resistance and microstructure of mortar, Powder Technol. 254 (2014) 314-323. 